\title{
Study the Agriculture Wasted of Natural Short Sisal Pulp to Rein Forced Epoxy for the used Composites Sheet Materials
}

\author{
Anupam Kumar ${ }^{1}$, Ramratan ${ }^{2 *}$ and Rohit Kumar ${ }^{3}$ \\ ${ }^{1}$ Professor, Department of Textile Engineering, Maharaja Ranjit Singh Punjab Technical University, India \\ ${ }^{2}$ Assistant Professor, Department of Textile Engineering, Maharaja Ranjit Singh Punjab Technical University, India \\ ${ }^{3}$ Research Scholar, Department of Textile Engineering, Maharaja Ranjit Singh Punjab Technical University, India
}

Submission: May 18, 2020; Published: June 16, 2020

*Corresponding author: Ramratan, Department of Textile Engineering, Giani Zail Singh Campus College of Engineering and Technology, Maharaja Ranjit Singh Punjab Technical University, Bathinda-151001, Punjab, India

Abstract

In this study it has been aimed to use sisal fibres pulp in composite materials and to study the mechanical properties of the produced samples. The mechanical tests results (thickness test, tensile strength and impact strength tests) and SEM micrographs indicated sisal fibres as an alternative natural fibre source for developing reinforced composites for various industries. The content of sisal fiber pulp is varied (35\%, $45 \%, 55 \%)$ weight percentage whereas the epoxy resin is varied (50\%, 40\%, 30\%) percentage is kept constant $15 \%$ in hardener. Composites have been fabricated using hand layup technique using a suitable mold developed in industry. All the sample have been tested in universal testing machine as per ASTM standard for tensile strength and impact strength it is observed that composite with 35\% paddy pulp is having highest tensile strength of $4 \mathrm{~mm}(4.08 \mathrm{Mpa})$ and $8 \mathrm{~mm}(7.91 \mathrm{Mpa})$. The impact strength of composite with $35 \%$ sisal fiber pulp was highest than $45 \%$ to $55 \%$ sisal fiber pulp. The composites were tested by tensile strength testing and impact strength tester.

Keywords: Short sisal fiber pulp; Epoxy resin; Hardener; Tensile strength; Impact strength; SEM

\section{Introduction}

Nowadays most developed countries are paying special attention to environmental issue. Some of the most important action to protect the environment is focused on the optimum use of natural resources. Researches have begun to focus attention on natural fiber composites (i.e. coir, jute, sisal, banana, hemp fibers) which are composed of natural or synthetic resins, reinforced with natural fibers [1]. Natural fibers exhibit many advantageous properties; they are low density natural yielding relatively light weight composites with high specific properties. These fibers also have significant cost advantages and ease of processing along with being highly renewable resources. Natural fiber composites are very cost-effective material especially in building and construction purpose packaging, automobile and railway coach interiors and storage devices [2,3]. Composite material depends on the properties of constituent material the fiber and the resin used. At present day, the advance composites material has been broadly used composite in the engineering field due to their noble mechanical properties. A lot of advanced research literature is mentioned on natural fiber reinforced green composites in the way of refining mechanical strength and mark them suitable in many engineering applications [4-6]. Because of these aims the attention of Composite material going in the direction of the green composites. Which do not have a negative effect on the environment and they are biodegradable, full sustainable, environment friendly in nature. All the above reasons force the researches to develop material that are biodegradable in nature and have good mechanical properties. Natural fiber is composed of cellulose, Hemicelluloses and Lignin and pectin. This resulted in the important problem of compatibility between pulp and matrix due to weakness in the adhesion between to surface fiber and the polymer matrix so changing the fiber surface by treatment $[7,8]$.

The values of different plant fibers and compared it with glass fibers. The tensile strength and the Young's modulus of the synthetic fibers are visibly much higher than that of the natural fibers. However, the difference in the specific values of synthetic and natural fiber, most important with respect to applications, is not as great. Jute, sisal and flax have similar and better mechanical properties compared to other natural fibers [9]. Further the jute 
fibers are less dense than flax [6]. In this work experimental investigation is carried out on free vibration characteristics of short sisal fiber (SFPC) and short banana fiber (BFPC) polyester composites and is found that 50:50 ratio of resin and fiber volume fraction gives good result. Further length of the fibers is also considered. Damping nature of the fibers is also studied [10]. The investigation carried on mechanical properties, odor emission and structure properties of abacca, jute and flax fibers and reveals that jute is found to have superior tensile and flexural modulus than the other two [11]. The prepared starch-based batters incorporating jute, flax fibers inside a hot mold. Compared to flax, jute had more reinforcing effect (observed from the SEM photographs) than flax fibers [12]. Use of these fibers saves environment and also reduces the energy consumption which is required in processing manmade fibers. It is also coated that more research has to be carried out on the natural fibers to avoid any set back during the finalization from lab scale to commercial level [13].

This present research works short sisal fibres pulp reinforced epoxy composite material sheet has been utilised with $35 \%$, $45 \%, 55 \%$. But previous literature view studies according to be utilised sisal fibre composite sheet $15 \%$ to $25 \%$. Application of high-performance composites using natural fibers is increasing in various engineering field. Composite material comprising one or more phase belonging to natural or biological origin. The composites produced to day with the incorporation of natural fiber as rein forcements. In epoxy matrix are used for boat hulls, surfboards, sporting goods, building panel this not only reduces the cost but also save from environmental pollution.

\section{Material and Methods}

\section{Material}

Preparation of test sample: Short sisal fiber length $(1 \mathrm{~mm})$ Put $1 \mathrm{~kg}$ dried fiber in the cooking pot. Make a solution of sodium hydroxide and soda anthraquinone pour the solution in the pot with sisal fiber and boil for 3 hours. After that, it will become pulp and we will wait for it to cool down and wash him with water three or four time, after that we will blend with the help of blending machine and then we will are squeeze with help of cotton fabric after that, the polyester resin and hardener mixed in a container and Stirred well for 3 to 5 minutes. The sisal fiber pulp was then added gradually and stirred to allow proper dispersion of fiber within the gel like mixture. Before the mixtures were poured inside the mould, the mould was initially polished with a release agent to prevent the composites from sticking to the mould upon removal. Finally, after the mixture had been poured into the mould, it was left at for 3 to 4 day. For fully cured and hardened (Figure 1).

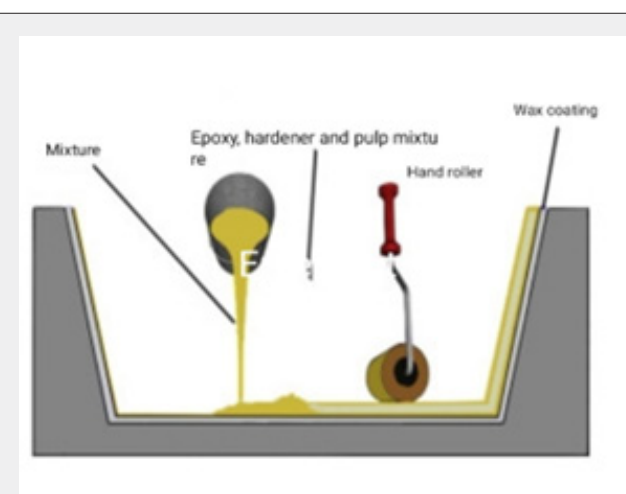

Figure 1: (a) Mould Assembly.

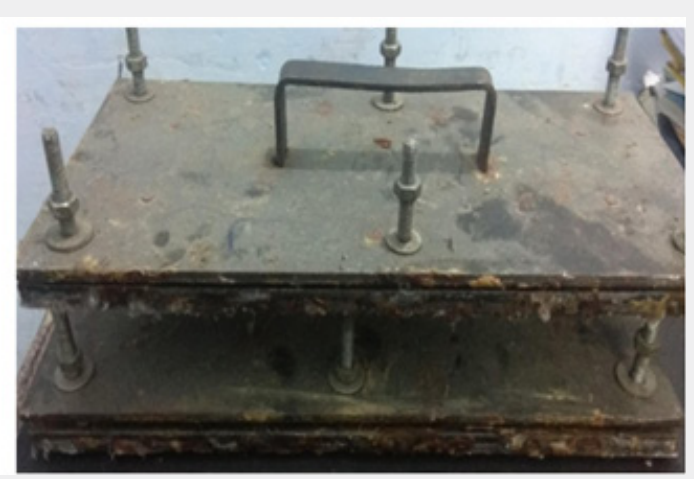

(b) Iron mould.
Epoxy: Molecular with many no. of epoxy group, which can be hardened into a usable plastic. epoxy resin is produced from combining epichlorophydrin and bisphenol.

Hardener: To convert epoxy resin to epoxy plastic a reaction take place with a suitable substance

Sisal fibers: The physical and mechanical characteristics of sisal fibers are given in (Table 1) and the chemical composition of sisal fiber. The characteristics of the fibers depend on the properties of the individual constituents, the fibrillar structure and the lamellae matrix. The fibre cells are linked together by means of middle lamellae, which consists of hemicelluloses, lignin and pectin (Figure 2) (Table 1-3).

\section{Methods}

Thickness testing: For measuring the thickness of a wire or a plate, calipers micrometer is used. Principal of the measurement of sheet thickness, the thickness test was performed as per ASTMD - 1777 standard.

Tensile strength testing: Tensile strength is the ability of material to resist the forces that pulls it apart or it is the resistance of material to breakage under tension. The tensile test was performed as per ASTMD - 638 standards. For tensile testing the Specimen were cut as per the dimensions, detailed dimensions for this are shown in (Figure $3 \&$ Table 4 ) the test were conducted using a universal testing machine (UTM). Two sample of each composite were tested and their mean value is taken (Figure $4 \& 5$ ). 


\section{International Journal of Environmental Sciences \& Natural Resources}

Tensile strength $=$ maximum load $/$ Area of Specimen

Impact strength: Test impact strength is the ability of a material to absorb impact energy without breaking. Impact test are performed to know the toughness of material. The Specimen was subjected to a large amount of force for a small interval of time. A material with more impact energy will have more toughness. The impact test was performed as per ASTMD -256 standards for impact testing the Specimen were cut as per the dimensions, detailed dimensions for this are shown in (Figure 6 \& Table 5) impact Specimen shape (Figure 7 \& 8).
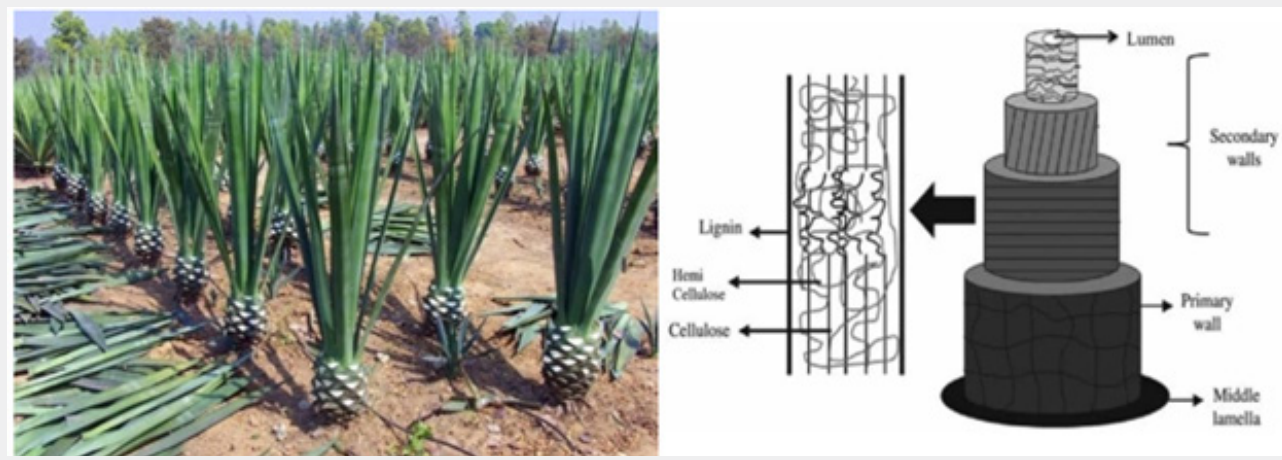

Figure 2: (a) Sisal plant.

(b) Schematic sketch of a sisal fiber.

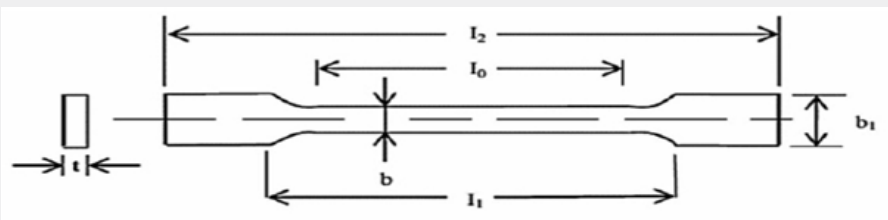

Figure 3: Tensile specimen dimensions shape.

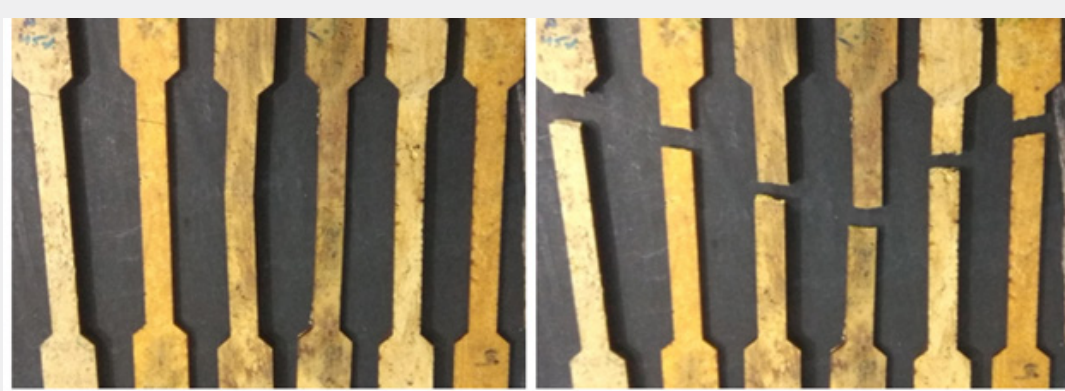

Figure 4: (a) Tensile specimen dimensions shape.

(b) After tensile testing.

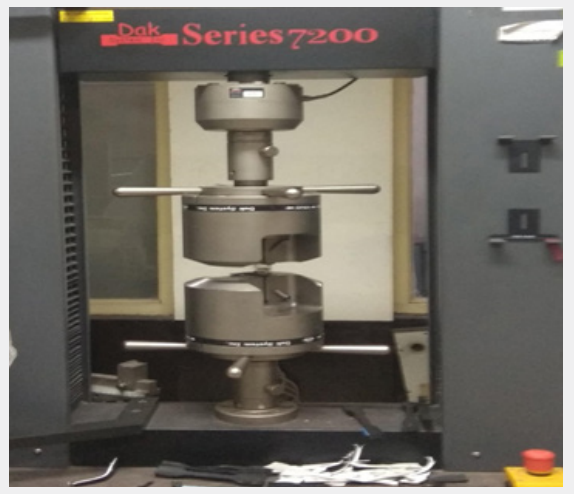

Figure 5: Tensile strength instruments. 


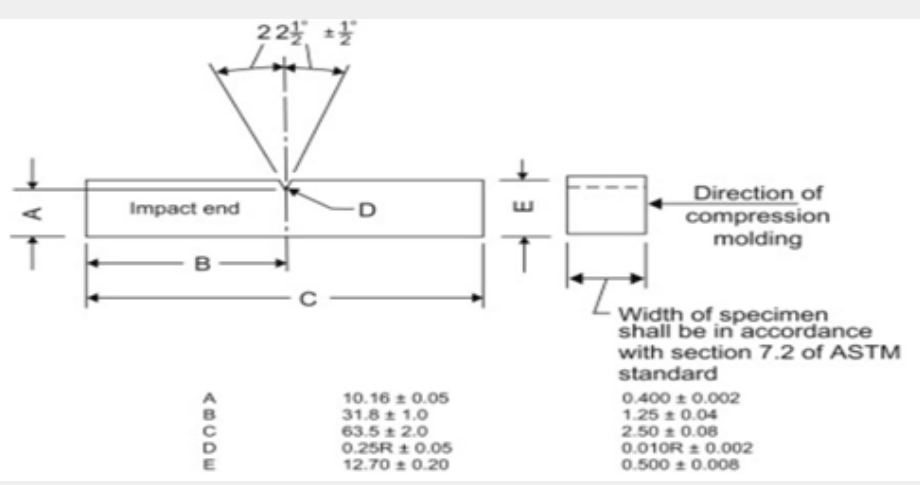

Figure 6: Impact Specimen dimension.

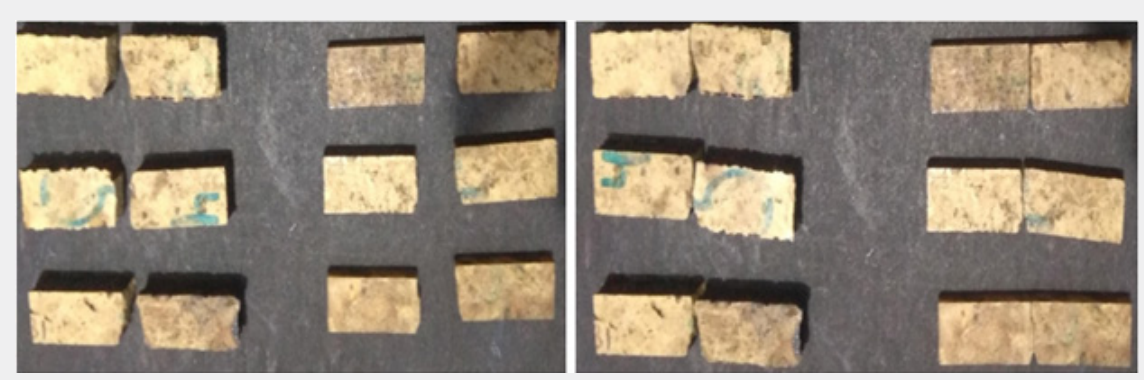

Figure 7: (a) After impact strength testing.

(b) Impact Specimen.

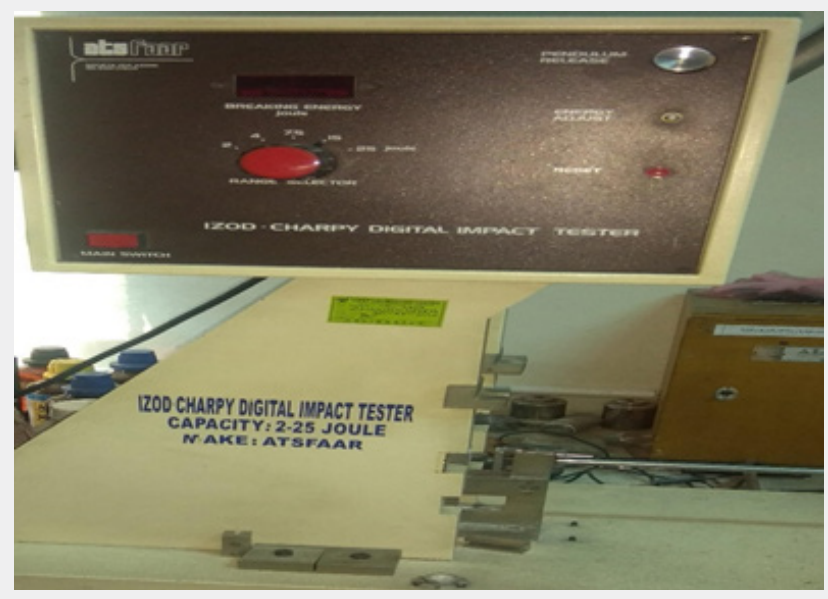

Figure 8: Impact strength instruments.

Table 1: Chemical composition of sisal fiber.

\begin{tabular}{|c|c|c|}
\hline S. no & Composition & Range (\%) \\
\hline 1 & Cellulose & $66-72$ \\
\hline 2 & Hemicelluloses & 12 \\
\hline 3 & Lignin & $10-14$ \\
\hline 4 & Moisture content & 11 \\
\hline
\end{tabular}


Table 2: The physical and Mechanical characteristics of sisal fiber.

\begin{tabular}{|c|c|c|c|c|c|c|}
\hline Fiber & $\begin{array}{c}\text { Diameter (mi- } \\
\text { cro-m) }\end{array}$ & $\begin{array}{c}\text { Density (kg/ } \\
\mathbf{m}^{\mathbf{3}} \mathbf{)}\end{array}$ & $\begin{array}{c}\text { Tensile Strength } \\
\text { (Mpa) }\end{array}$ & $\begin{array}{c}\text { Tenacity } \\
\text { (Mpa) }\end{array}$ & $\begin{array}{c}\text { Elastic Modulus } \\
\text { (Gpa) }\end{array}$ & $\begin{array}{c}\text { Elongation at Break } \\
\text { (\%) }\end{array}$ \\
\hline Sisal & $50-200$ & 1450 & $400-700$ & $568-640$ & $09-12$ & $06-14$ \\
\hline
\end{tabular}

Table 3: Specimen composites.

\begin{tabular}{|c|c|c|c|c|}
\hline S.no & Thickness(mm) & Pulp Ratio (\%) & Epoxy Resin (\%) & Hardener (\%) \\
\hline 1 & 4 & 35 & 50 & 15 \\
\hline 2 & 4 & 45 & 40 & 15 \\
\hline 3 & 4 & 55 & 30 & 15 \\
\hline 4 & 8 & 35 & 50 & 15 \\
\hline 5 & 8 & 45 & 40 & 30 \\
\hline
\end{tabular}

Table 4: Tensile specimen dimension size.

\begin{tabular}{|c|c|c|c|}
\hline S.no. & Symbol & Description & Dimension(mm) \\
\hline 1 & I0 & Gauge length & 145 \\
\hline 2 & I1 & Grip distance & 160 \\
\hline 3 & I2 & Overall length & 240 \\
\hline 4 & B & Width of narrow parallel portion & 15 \\
\hline 5 & b1 & Width end & 30 \\
\hline 6 & T & Thickness & 4,8 \\
\hline
\end{tabular}

Table 5: Impact Specimen dimension.

\begin{tabular}{|c|c|c|}
\hline S. no & Description & Dimension (mm) \\
\hline 1 & Length of Specimen & 63.5 \\
\hline 2 & Centering of notch & 2.54 \\
\hline 3 & Radius of notch type V & 0.25 \\
\hline 4 & Angle of notch & $45^{\circ}$ \\
\hline 5 & Width & 12.7 \\
\hline 6 & Thickness & 4,8 \\
\hline
\end{tabular}

Results and Discussion

(Table 6-10)

Table 6: Sheet thickness test.

\begin{tabular}{|c|c|c|c|}
\hline Pulp Ratio (\%) & Various Thickness (mm) & Mean & Thickness (mm) \\
\hline 35 & $4.06,4.22,4.26,4.32,4.13,4.19,4.42,4.54,4.63,4.38$ & $43.15 / 10$ & 4.315 \\
\hline 45 & $4.23,4.27,4.31,4.35,4.42,4.18,4.22,4.37,4.51,4.56$ & $43.42 / 10$ & 4.342 \\
\hline 55 & $4.09,4.11,4.15,4.17,4.21,4.27,4.29,4.34,4.37,4.54$ & $42.54 / 10$ & 4.254 \\
\hline 35 & $8.12,8.21,8.24,8.31,8.33,8.37,8.43,8.56,8.67,8.53$ & $83.77 / 10$ & 8.377 \\
\hline 45 & $8.16,8.21,8.41,8.23,8.29,8.37,8.82,8.92,8.14,8.19$ & $83.74 / 10$ & 8.374 \\
\hline 55 & $8.24,8.32,8.36,8.42,8.62,8.69,8.72,8.77,8.82,8.39$ & $85.35 / 10$ & 8.535 \\
\hline
\end{tabular}




\section{International Journal of Environmental Sciences \& Natural Resources}

Table 7: Sample GSM.

\begin{tabular}{|c|c|c|c|c|}
\hline S.no & Pulp Ratio (\%) & Thickness $(\mathbf{m m})$ & Weight $(\mathbf{g m})$ & $\mathbf{G S M}\left(\mathbf{g} / \mathbf{m}^{\mathbf{2}}\right)$ \\
\hline 1 & 35 & 4 & 152 & $152 \mathrm{gm} / 0.03=5066$ \\
\hline 2 & 45 & 4 & 147 & $147 \mathrm{gm} / 0.03=4900$ \\
\hline 3 & 55 & 4 & 139 & $139 \mathrm{gm} / 0.03=4633$ \\
\hline 4 & 35 & 8 & 238 & $238 \mathrm{gm} / 0.03=7933$ \\
\hline 5 & 45 & 8 & 232 & $232 \mathrm{gm} / 0.03=7733$ \\
\hline 6 & 55 & 8 & 223 & $223 \mathrm{gm} / 0.03=7433$ \\
\hline
\end{tabular}

Table 8: Sample density.

\begin{tabular}{|c|c|c|c|}
\hline S.no & Pulp Ratio (\%) & Thickness $(\mathbf{m m})$ & Density $\left(\mathbf{g} / \mathbf{m}^{3}\right)$ \\
\hline 1 & 35 & 4 & $152 \mathrm{gm} / 120=1.266$ \\
\hline 2 & 45 & 4 & $147 \mathrm{gm} / 120=1.225$ \\
\hline 3 & 55 & 4 & $139 \mathrm{gm} / 120=1.158$ \\
\hline 4 & 35 & 8 & $238 \mathrm{gm} / 240=0.991$ \\
\hline 5 & 45 & 8 & $232 \mathrm{gm} / 240=0.966$ \\
\hline 6 & 55 & 8 & $223 \mathrm{gm} / 240=0.921$ \\
\hline
\end{tabular}

Table 9: Tensile strength result.

\begin{tabular}{|c|c|c|c|c|c|}
\hline S. no & $\begin{array}{c}\text { Pulp Ratio } \\
(\mathbf{\%})\end{array}$ & $\begin{array}{c}\text { Thickness } \\
(\mathbf{m m})\end{array}$ & $\begin{array}{c}\text { Tensile Strength 1 (Mpa) AST- } \\
\text { MD- 638 }\end{array}$ & $\begin{array}{c}\text { Tensile Strength 2(Mpa) ASTMD } \\
\mathbf{- 6 3 8}\end{array}$ & $\begin{array}{c}\text { Mean Tensile } \\
\text { Strength }\end{array}$ \\
\hline 1 & 35 & 4 & 3.75 & 4.42 & 4.08 \\
\hline 2 & 45 & 4 & 3.12 & 4.1 & 3.61 \\
\hline 3 & 55 & 4 & 3.03 & 2.15 & 2.59 \\
\hline 4 & 35 & 8 & 8.36 & 7.47 & 7.91 \\
\hline 5 & 45 & 8 & 6.27 & 4.52 & 5.39 \\
\hline 6 & 55 & 8 & 4.72 & 3.68 & 4.2 \\
\hline
\end{tabular}

Table 10: Impact Specimen result.

\begin{tabular}{|c|c|c|c|c|c|}
\hline S.no & $\begin{array}{c}\text { Pulp Ratio } \\
\%\end{array}$ & $\begin{array}{l}\text { Thickness } \\
\text { (mm) }\end{array}$ & $\begin{array}{c}\text { Impact Energy } 1\left(\mathrm{Kj} / \mathrm{m}^{2}\right) \text { ASTMD } \\
256\end{array}$ & $\begin{array}{c}\text { Impact energy } 2\left(\mathrm{Kj} / \mathrm{m}^{2}\right) \text { ASTMD } \\
256\end{array}$ & $\begin{array}{l}\text { Mean } \\
\text { Strength }\end{array}$ \\
\hline 1 & 35 & 4 & 1.23 & 2.14 & 1.68 \\
\hline 2 & 45 & 4 & 1.42 & 1.13 & 1.27 \\
\hline 3 & 55 & 4 & 2.02 & 1.19 & 1.6 \\
\hline 4 & 35 & 8 & 3.07 & 2.53 & 2.8 \\
\hline 5 & 45 & 8 & 2.74 & 2.76 & 2.75 \\
\hline 6 & 55 & 8 & 2.18 & 2.06 & 2.12 \\
\hline
\end{tabular}

Fractured surface morphology using field Emission scanning Electron microscope (FESEM)

SEM is basically an electron microscope that images the sample surface by scanning it with a high. Energy beam of electrons. The signals produced by SEM result from interaction of the electron beam with atom at or near the surface of the sample SEM can produce very high-resolution images of a sample surface revealing details about less than 1 to $5 \mathrm{~min}$ in size due to the very Narrow electron beam. SEM micrographs have a large depth of field yielding a characteristic three-dimensional appearance useful for understanding the surface of a sample show below Figure $9(a, b)$.

\section{Density for the composite sheet}

a) The Density testing was done on six composites plate and the results are noted in form of Table 8.

b) As we can see that as fiber to resin ratio, when the percentage of fiber is decreased, we have increase in density of composite. 


\section{International Journal of Environmental Sciences \& Natural Resources}

c) As per shows (Figure 10) analysis of composite plates of Density module of composites.

d) The increase in fiber percent gives higher density as analyzed by the graph.

\section{Tensile strength for the composite sheet}

Six different type of Composite sample are tested in dak series 7200 machine name universal testing machine. Sample are lift to break till the ultimate strength occurs. The figures Table 9 shows the variations in tensile strength of different sample.

a) As we can see the above table readings the tensile testing, the results up to $35 \%$ pulp Ratio composition the reading is highest

b) The tensile testing was done on six composite sheet and result are noted in form of (Table 9 \& Figure 11)
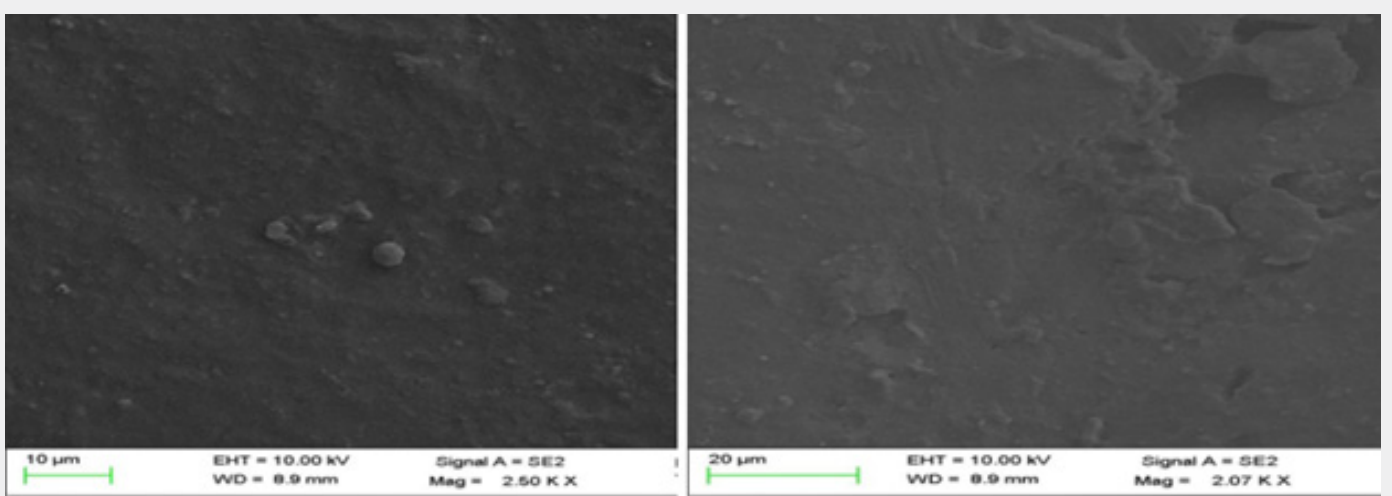

Figure 9: (a) Different beam light penetration of the SEM images for Composite sheet.
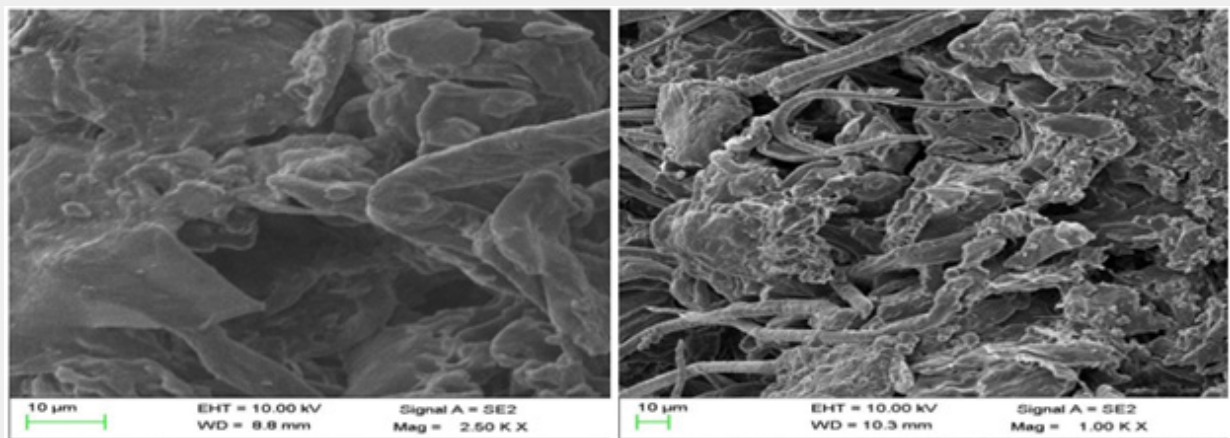

(b) Different beam light penetration of the SEM images for Composite sheet.

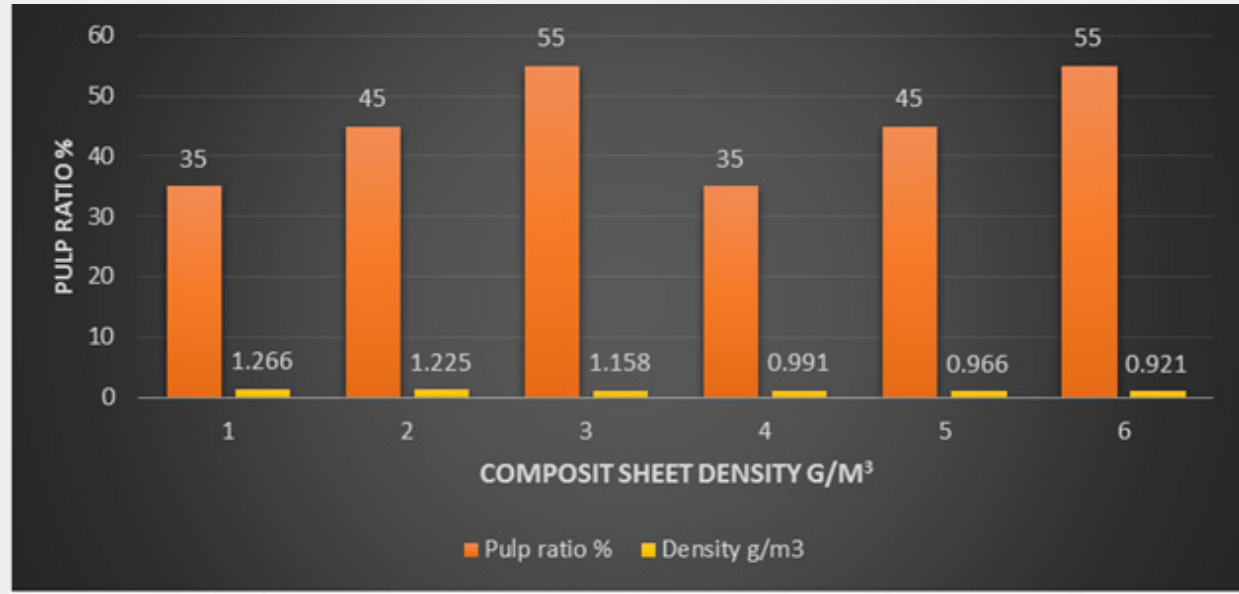

Figure 10: Effect of the pulp ratio on Density properties. 
c) As per show the below (Figure 11), it clearly analyzes the data which lead to highest tensile strength of composite plate having composition of $35 \%$ fiber and $50 \%$ resin.

\section{Impact for the composite sheet}

The impact capability of sample impact test is carried out using Izod - charpy digital impact testing machine. Absorbed energy obtained for six different composite sample from the machine. The Table 8 shows the variation in impact strength of different samples.

a) The impact strength testing was done on six composite plate and the result are noted in form of Table 10.

b) As we see that as pulp to resin ratio, when the percentage of Fiber is decrease, we have increase in impact strength of composite

c) As per shown Figure 12, analysis of composite plate of impact strength of composite
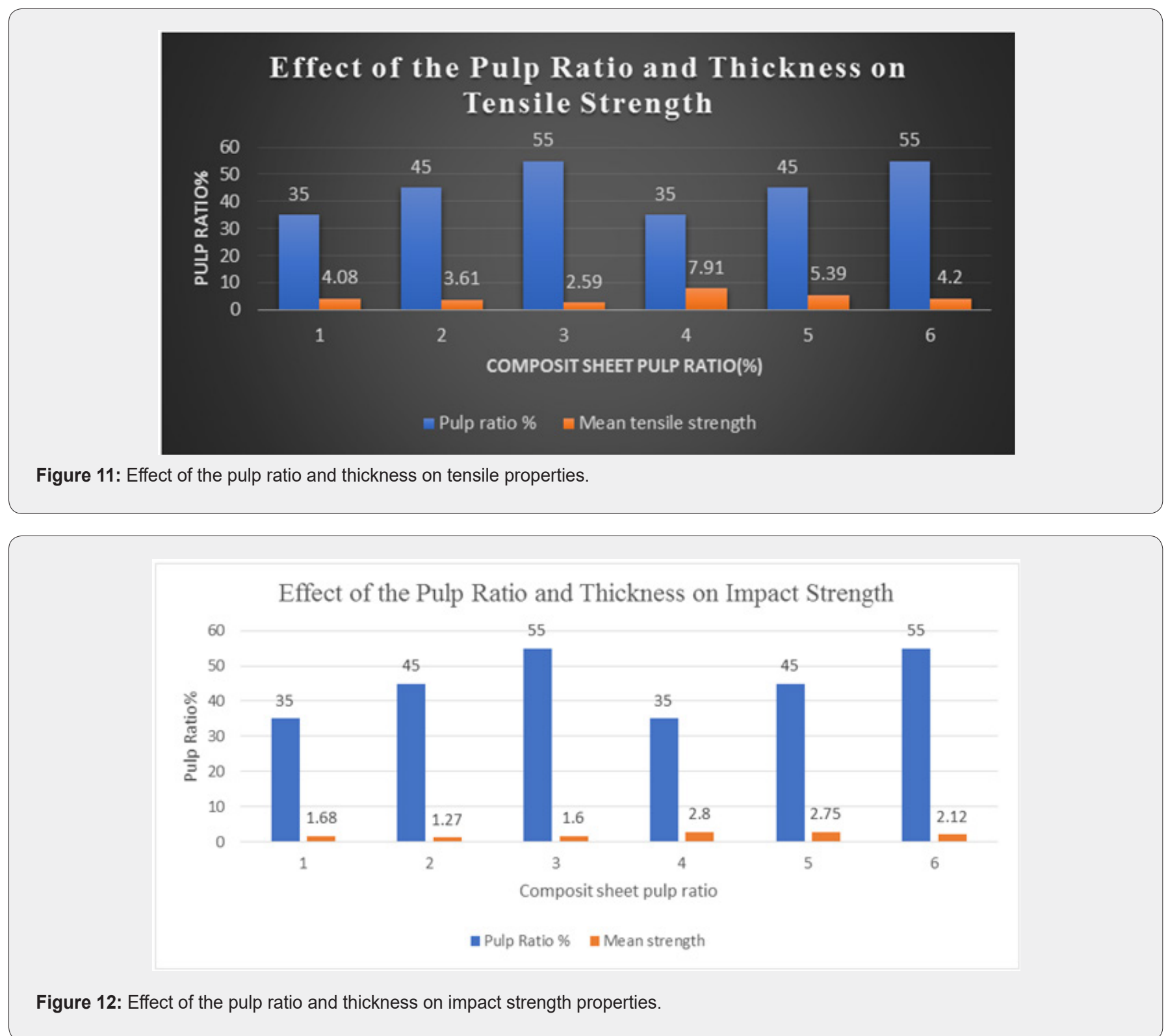

\section{Conclusion}

Accumulation of unmanaged agro waste especially from the developing countries has an increased environmental concern. Develop a natural particulate composite material with better strength and to study the physical and mechanical characteristics of the composite material. This process leads to finding the optimum composition and methodology to manufacture such a composite material. the results of the work show that a useful composite with good properties could be successfully development using sisal fibre pulp as reinforcing agent for the polymer of composites 
tensile strength and impact strength. This process leads to finding the optimum composition and methodology to manufacture such a composite material.

This study involves mechanical Characterisation of properties of sisal fibre pulp epoxy resin composites. experimental and analytical observation of pulp or resin composites leads to following.

a) The decrease in pulp percentage give higher density of composites sheet.

b) As we can see that as pulp to resin ratio, when the percentage of pulp is increasing, we have decrease in tensile strength.

c) The decrease in pulp percentage give higher impact strength of composite sheet.

\section{Acknowledgement}

The Authors wishes to express their heartfelt gratitude to the authorities of GZSCCET bathinda to provide the facilities for conducting the required test in their laboratories. Special thanks are also due to HOD and staff of textile Engineering Department of Giani Zail Singh Campus College of engineering and technology, without whose help this work would not have been completed.

\section{References}

1. Joseph K, Toledo FRD, James B, Thomas S, de Carvalho LH (1999) A review on sisal fibre reinforced polymer composites. R Bras Eng Agric Ambienta Campina Grande 3(3): 367-379.

2. Naidu VNP, Reddy GR, Kumar MA, Reddy NM, Khanam PN, et al. (2011) Compressive \& impact properties of sisal fiber reinforced hybrid composites. International Journal of Fiber and Textile Research 1(1): 11-14.

3. Naidu VNP, Reddy GRC, Kumar MA (2011) Thermal conductivity of Sisal/Glass fibre reinforced hybrid composites. International Journal of Fiber and Textile Research 1(1): 28-30.
4. Dixit S, Verma P (2012) The Effect of Hybridization on Mechanical Behavior of coir/sisal /Jute fibres reinforced polyester composite material. Research Journal of Chemical Sciences 2(6): 91-93.

5. Yan Li, Yiu-Wing Mai, Lin Ye (2000) Sisal fibre and its composites: a review of recent developments. Composites Science and Technology 60(11): 2037-2055.

6. Bledzkia AK, Zhang W, Chate A (2001) Natural-fibre-reinforced polyurethane macrofoams. Composites science and technology 61(2): 2405-2411.

7. Kumar KS, Siva I, Jeyaraj P, Jappes JTW, Amico SC, et al. (2014) Synergy of fiber length and content on free vibration and damping behavior of natural fiber reinforced polyester composite beams. Materials and design 56(2): 379-386.

8. Bledzki K, Mamun AA, Faruk O (2007) Abaca fibre reinforced PP composites and comparison with jute and flax fibre PP composites. Institute for werkst offte chnik, kunst stoff- und recycling technik, University of Kassel, Mönchebergstrasse, Kassel, Germany.

9. Ishak MA, Maleque A, Belal FY, Sapuan SM (2007) Mechanical properties study of pseudo stem banana fiber reinforced epoxy composite. The Arabian journal for science and engineering 32(2): 359-364.

10. Ticoalu A, Aravinthan T, Cardona F (2010) A review of current development in natural fiber composites for structural and infrastructure applications. Centre of excellence in engineered fiber composites, University of Southern Queensland Toowoomba, Australia.

11. Khan GMA, M Terano M, Gafur MA, Alam MS (2016) Studies on the mechanical properties of woven jute fabric reinforced poly (Lactic Acid) composites. Journal of King Saud University Engineering Sciences 28(1): 69-74.

12. Mishra V, Biswas S (2013) Physical and mechanical properties of bidirectional jute fiber epoxy composites. Chemical, civil and mechanical engineering tracks of $3 \mathrm{rd}$ nirma university international conference on engineering. Procedia Engineering 51: 561-566.

13. Prabhakarana S, Krishnaraj V, Senthil kumar M, Zitoune R (2014) Sound and vibration damping properties of flax fiber reinforced composites. Department of robotics \& automation engineering, PSG College of Technology, Coimbatore-641004, India. Procedia Engineering 94: 573581.

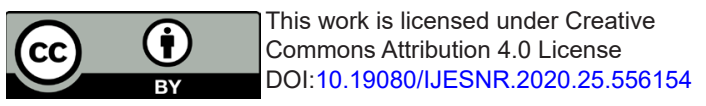

